\title{
The Use of Cuprous Oxide and other Rectifier Photo Cells in Submarine Photometry.
}

\author{
By \\ W. R. G. Atkins, Sc.D., F.R.S., \\ Head of the Department of General Physiology at the Plymouth Laboratory, \\ And \\ H. H. Poole, Sc.D., \\ Registrar of the Royal Dublin Society. \\ With 1 Figure in the Text.
}

THE cuprous oxide cell introduced by Lange (1930) differs greatly from the photo-electric cells heretofore in general use. The sensitivity is high and no high-tension battery is needed in the circuit. There are, however, certain limitations to the use of such rectifier cells for daylight photometry; these we have considered elsewhere (1933). The types dealt with include cuprous oxide cells of both French and German origin and a selenium rectifier cell, introduced by Bergmann (1931) and made by the Süddeutschen Apparate-Fabrik, Nürnberg, and under license by the Weston Electrical Company, from which our cell was obtained. The latter arrived too late for use in submarine measurements in the summer of 1932, but is to be preferred to the cuprous oxide type. There is another type of rectifier, the Bernheim cell, which is made in Paris. This we have not examined as yet, but from data supplied by the makers its spectral sensitivity is similar to that of the Bergmann cell, which it also resembles in its high sensitivity and improved stability.

\section{The Submarine Photometer.}

This was intended for shore work, so that it could be carried about in a diver's hand. It consists of a circular gun-metal box, $9 \cdot 6 \mathrm{~cm}$. diameter, flanged at the top and fitted with a ring; between ring and flange a $0 \cdot 6 \mathrm{~cm}$. disc of plate glass was fitted and secured. Above this the usual disc of opal flashed glass could be placed, with a colour filter in between if so desired. Two of the flange screws had projections with holes for attaching a light rope.

A "Serpidox" photo-electric cell, Sx80, obtained from the Société de Recherches et de Perfectionnements Industriels, Puteaux (Seine), was 
mounted immediately below the window, and beside it a small amount of calcium chloride was held in a bag.

The cable entered through a side tube with slightly bulbous nozzle, a water-tight joint being effected by means of thick pressure tubing. Six hundred megohm "cab-tyre" twin cable was used; a length of $45 \mathrm{~m}$. sufficed for the coastal work and weighed $4.5 \mathrm{~kg}$. The photometer weighed $3.2 \mathrm{~kg}$., as against $22 \mathrm{~kg}$. the weight of that formerly in use at sea. It was reported as convenient to hold and not too heavy under water.

\section{The Air Photometer, Galvanometer, Shunt, and Connections.}

A similar "Serpidox" cell, No. Sx81, was used to measure the illumination in air. It was placed on a level rock, unmounted, but covered with the usual opalized glass and a water filter to lessen temperature errors. Both photometers were connected to a throw-over switch and to the special shunt. When received the two Serpidox cells were closely the same in sensitivity, but when mounted in the submarine photometer the greater distance of the cell from the opal resulted in the ratio of the readings in air, when both were under water screens, being on the average $0 \cdot 75$.

For measuring the current we found a Cambridge Instrument Co. "Versatile Galvanometer," weighing $1.8 \mathrm{~kg}$., to be suitable. Its resistance is $10 \mathrm{ohms}$, and each scale division corresponds to $2 \mu \mathrm{a}$; the scale (upper) reads to 120 , viz. $240 \mu \mathrm{a}$. With this instrument we made use of a shunt, specially designed to keep the resistance $10 \mathrm{ohms}$ always ; this permitted the ranges $1,5,10$, and 50 to be used, and is figured in our previously mentioned paper.

\section{Phe Standardization of the Photometers.}

In view of the lack of strict proportionality between current and intensity and of the change of sensitivity with time and exposure, it is necessary to standardize each cell against a vacuum photo-electric cell of the usual type. This was done on the Laboratory roof, over an extended range, using the potentiometer method. Low intensities were measured in a north window, using a galvanometer instead of a potentiometer. The Serpidox cell was connected to the 10-ohm galvanometer throughout. The results are shown in Figure 1, curves A and B.

As the change of sensitivity with time may depend on the intensity, the sensitivity of the cell should be checked at two or three different sensitivities from time to time.

From the form of the voltage curve, C, obtained with the rectifier cell connected directly to the No. 2 circuit of the potentiometer outfit, but with the vacuum cell connected as usual, it may be seen that this cell 
could be used at sea with the potentiometer outfit, viz. under conditions precluding the use of ordinary galvanometers. Illuminations can be read off from the curve, though indeed for low illuminations up to 10,000 metre candles, the deviation from a straight line is but slight in the case of a

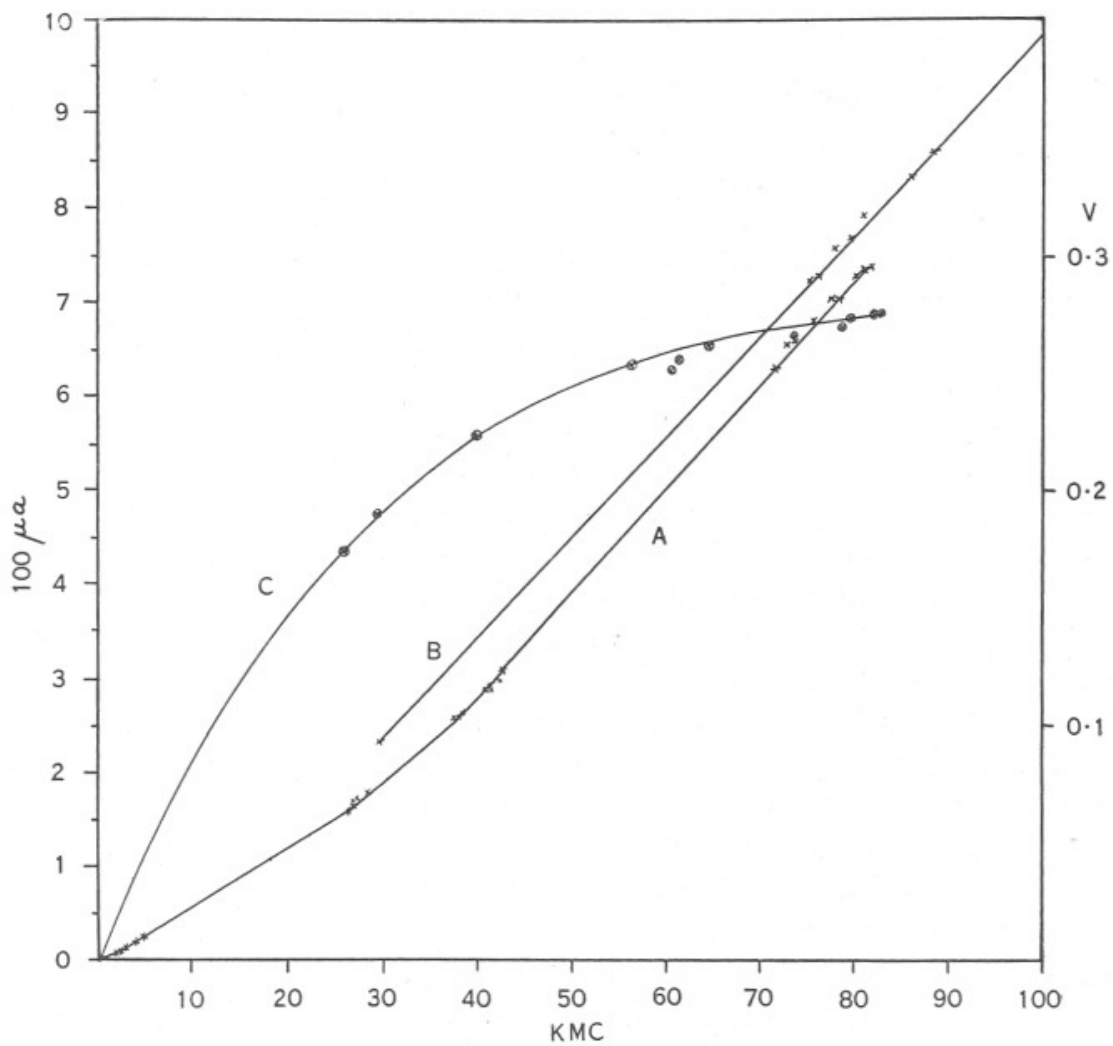

FIG. 1.-The abscissæ show vertical illuminations in thousands of metre candles (k.m.c.). The left-hand ordinates show current in $100 \mu \mathrm{a}$ units. The right-hand ordinates show E.M.F. in volts on open circuit.

Curve A gives the behaviour of a cuprous oxide cell (Sx81) when cold, curve B when the sun had warmed it up, though under a water heat filter. Curve $\mathrm{C}$ shows the voltage relation, as determined with the submarine potentiometer outfit, measuring illumination with vacuum cell and taking the voltage of the cuprous oxide cell directly connected to the No. 2 circuit.

Serpidox cell. Those of other types give marked curvature in bright light on open circuit.

The sensitivity with the voltage measurement is about the same as with the low resistance galvanometer, for approximately 10,000 m.c. gives $200 \mu \mathrm{a}$ or $0 \cdot 0800$ volts. The former can be read to $0 \cdot 2 \mu \mathrm{a}$ or 10 m.c., the latter to 0.05 m.v. or 6.2 m.c. Voltage readings with "open circuit" or high resistance instruments are, however, more affected by 
temperature errors than current measurements with a low resistance galvanometer.

In carrying out such open-air standardizations one is faced with the problem of the variation of the light, which is rarely constant from one minute to another. The steadiest light is obtained with a clear sun and a clear blue sky at noon, or with a clear sun and clouds moving slowly. A hazy sky is liable to considerable variation in the degree to which the sun is obscured and a grey sky is normally very variable. Good results can be obtained, as at sea, by taking the average of a series of potentiometer readings for each photometer, or on land by two observers reading galvanometers simultaneously. In the standardizations shown in curve $\mathrm{C}$, series of potentiometer readings were made, but for curves $\mathrm{A}$ and $\mathrm{B}$ one observer made absolutely simultaneous observations by sound and sight; as the galvanometer was read the potentiometer dial was adjusted to minimum sound in the telephone, then after dictating the reading the potentiometer scale was read. Owing to the difference in the colour sensitivity of the potassium and the copper oxide rectifier cells the ratio of the sensitivities will depend on the relative amount of sunlight, much as when the CMV6 type of cell is being standardized.

We cannot, however, use the readings of the submarine photometer, after standardization against the air photometer (both under water screens), to measure the illumination at various depths in the sea without introducing a factor to correct for reflection losses at the surface of the opal and internal reflection effects in the opal and between it and the surface of the sea. These we have considered fully elsewhere (1933, a). The illuminations recorded have to be multiplied by a factor 1.09 in order to give the true under-water values. Thus, since the submarine photometer was less sensitive than the air photometer, even in air, its readings must be multiplied by 1.33 to make the two agree. When the submarine photometer is in water a further factor 1.09 must be used to correct for surface effects. The procedure is to read off the illumination, on the figure, for the current given by the submarine photometer and then to divide this reading by 0.75 and to multiply it by 1.09 , or in one operation to multiply by $1 \cdot 45$. For example, a reading of $200 \mu \mathrm{a}$ corresponds for the air photometer to $31 \cdot 0$ thousand metre candles (k.m.c.), but for the submarine photometer, when submerged below about $10 \mathrm{~cm}$. or any greater depth, $200 \mu \mathrm{a}$ corresponds to $31 \cdot 0 \times 1 \cdot 45=44.9$ k.m.c. Were we, however, to multiply the current $(200 \times 1 \cdot 45=290 \mu \mathrm{a})$, and then to read off from the figure, the result would, incorrectly, be $41 \cdot 0$ k.m.c. The difference is due to the curvature in the current illumination relation. In a similar manner submarine illuminations may be obtained from the voltage-illumination curve, but in this case the departure from a rectilinear relationship is very marked. For use under damp conditions, such 
as would arise where a cabin was not available on a ship or in northern latitudes, the fact that high insulation is no longer necessary and " dark currents " are negligible, since no high-tension battery is required, must be regarded as greatly favouring the use of this type of cell. Under normal conditions on a ship the ordinary vacuum cells have so much to recommend them in the way of greater accuracy that it would seem wise, for the present at any rate, to continue to use them. For approximate work on the coast, where the illumination is of necessity very variable, the cuprous oxide or other rectifier type of cell has the great advantage of portability in the measuring apparatus required, and the cell itself is quite accurate enough, if its limitations are remembered; it requires, of course, to be standardized against a vacuum cell.

We are indebted to Mr. J. A. Kitching and to Mr. G. Gilson for descending with a diving helmet on the coast near Wembury, Devon, and holding the photometer in positions of ecological interest. The results will be presented by them in their survey which includes the percentage of the diffuse light in air, as determined at a given tidal level, found where various algæ, Himanthalia, Laminaria, etc., were growing. From measurements of the coefficient of absorption of the water, the illumination in the different zones could be calculated for other states of the tide. The absorption coefficient would increase greatly in rough weather and decrease in very calm weather, but during the diving operations on August $3 \mathrm{rd}, 1932$, it was about $0 \cdot 5$, for vertical absorption. The figure is unduly high owing to diminution of light, not only by absorption, but by shading from the sides of the rocky gully investigated. We have, however, found water close to shore in rough weather to have $\mu_{\mathrm{v}}=0.8$ and even in very calm weather one could hardly expect it to be lower than $0 \cdot 3$, a value occasionally reached several miles out at sea. The date mentioned was the first that was possible for diving on such an exposed coast, after a period of stormy weather.

\section{SUMMARY.}

1. Photo-electric cells of the rectifier type are useful for approximate measurements of light intensity, in air or under water, using a lowresistance galvanometer, the current through which may be reduced by a special shunt keeping the circuit resistance constant.

2. Such an arrangement has proved serviceable for shore work, a light gun-metal photometer, housing a cuprous oxide cell, having been carried about by a diver.

3. These rectifier cells can also be used at sea, but instead of the current, the E.M.F. is determined by means of the potentiometer outfit as used at sea in previous years. 
4. The current-illumination relation is not rectilinear over a wide range of intensity; the current-voltage relationship shows very marked curvature.

5. The cuprous oxide cells have a considerable temperature coefficient and must be used with a water screen. The coefficient is smaller in the case of the selenium cell. Under prolonged exposure to light the sensitivity of the cuprous oxide cell decreases very considerably, but the selenium rectifier cell is far more stable.

6. Further laboratory and sunlight tests carried out with the Bergmann selenium cell while this paper was in the press, give great promise as to its suitability and convenience for daylight measurements in the field and under water, when due allowance is made for the curvature of its illumination: current characteristic.

\section{REFERENCES.}

Atkins, W. R. G., and Poole, H. H. 1933, a. The photo-electric measurement of the penetration of light of various wave-lengths into the sea and the physiological bearing of the results. Phil. Trans. Roy. Soc., London, Series B, 222, pp. 129-164.

Bergmann, L. 1931. Über eine neue Selen-Sperrschicht-Photozelle. Physik. Zeitschr., 32, pp. 286-288.

Lange, B. 1930. Über eine neue Art von Photozellen. Physik. Zeitschr., 31, pp. 139-140.

Poole, H. H., and Atkins, W. R. G. 1933, b. Some experiments on the suitability of rectifier photo cells for the measurement of daylight. Sci. Proc. Roy. Dublin Soc., 20, pp. 537-546. 